\title{
Assessment of the contamination of Lactuca sativa $L$. (lettuce) and Lycopersicon esculentum (tomato) by pesticides: Case of market gardeners in Ouagadougou
}

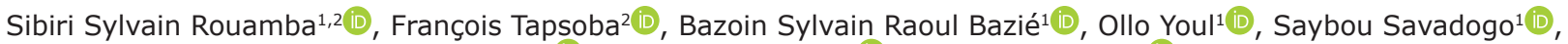
Elie Kabré ${ }^{1,3}$ (D), Lassana Sangaré ${ }^{3,4}$ (i) and Aly Savadogo² (D)

1. Laboratoire National de Santé Publique, 09 BP: 24, Ouagadougou 09, Burkina Faso, West Africa; 2. Laboratoire de Biochimie et Immunologie Appliquée, Université Joseph KI-ZERBO, 03 BP: 7131, Ouagadougou, Burkina Faso, West Africa; 3. Unité de Formation et de Recherche/Sciences De la Santé, Université Joseph KI-ZERBO, 03 BP: 7021 Ouagadougou 03, Burkina Faso, West Africa; 4. Service de Bactériologie-Virologie, Centre Hospitalier Universitaire Yalgado Ouédraogo, 03 BP: 7022 Ouagadougou 03, Burkina Faso, West Africa.

Corresponding author: Sibiri Sylvain Rouamba, e-mail: rousib@yahoo.fr

Co-authors: FT: tapsobaf@gmail.com, BSRB: bazsylvain@yahoo.fr, OY: youl.ollo@yahoo.com, SS: ssaybou0204@gmail.com, EK: elie.kabre@gmail.com, LS: sangarelassana01@gmail.com, AS: alysavadogo@gmail.com Received: 12-08-2021, Accepted: 27-10-2021, Published online: 11-12-2021

doi: www.doi.org/10.14202/IJOH.2021.251-256 How to cite this article: Rouamba SS, Tapsoba F, Bazié BSR, Youl O, Savadogo S, Kabré E, Sangaré L, Savadogo A (2021) Assessment of the contamination of Lactuca sativa L. (lettuce) and Lycopersicon esculentum (tomato) by pesticides: case of market gardeners in Ouagadougou, Int. J. One Health, 7(2): 251-256.

\begin{abstract}
Background and Aim: The use of pesticides in vegetable production can cause public health problems because these agrochemicals can leave residues in foodstuffs and disrupt the appropriate functioning of the organism. The aim of this study was to assess the level of contamination of lettuce and tomato by pesticide residues.

Materials and Methods: This study was conducted from February 12 to May 3, 2021, in concerned five market gardening sites in the city of Ouagadougou. A survey was conducted among 58 market gardeners selected at random from the sites of Boulmiougou, Tanghin No. 1 and 2, Bissigin, and the National School of Public Health. Simultaneously, 25 lettuce samples and 25 tomato samples were collected in a randomized manner for the examination and determination of pesticide residues using the quick, easy, cheap, effective, rugged, and safe method.
\end{abstract}

Results: The market gardening population was predominantly represented by women who had a low level of education. The cultivated species were a mixture of exotic cultures and traditional cultures. These crops were treated with various pesticides, the most common of which belonged to the organochlorine family. The tomato was the crop most contaminated by pesticide residues. However, no active ingredient from the synthetic pyrethroid family was found on lettuce or tomato.

Conclusion: Raising the awareness of market gardeners on good practices in the use of pesticides and on alternative methods to synthetic phytosanitary products is of paramount importance for the health of consumers.

Keywords: lettuce, market gardeners, Ouagadougou, pesticides, tomato.

\section{Introduction}

Today, agriculture, in general, and market gardening, in particular, must encounter several challenges such as not only increasing the food supply but also the requirement of agricultural production guaranteeing health security and quality, nutrition, and respect for the environment [1]. However, in several developing countries, regulations in terms of production techniques or the sanitary quality of agricultural production are either nonexistent or not accompanied by effective control of practices, inputs, and food products [1]. Therefore, market gardening in sub-Saharan Africa is often based on intensive, even abusive, use of inputs (mineral fertilizers, organic waste,

Copyright: Rouamba, et al. This article is an open access article distributed under the terms of the Creative Commons Attribution 4.0 International License (http://creativecommons.org/licenses/ by/4.0/), which permits unrestricted use, distribution, and reproduction in any medium, provided you give appropriate credit to the original author(s) and the source, provide a link to the Creative Commons license, and indicate if changes were made. The Creative Commons Public Domain Dedication waiver (http:// creativecommons.org/ publicdomain/zero/1.0/) applies to the data made available in this article, unless otherwise stated. phytosanitary products, and wastewater), with often harmful consequences for human, animal, and environmental health $[2,3]$.

Urban agriculture remains a key activity providing food, wealth, and jobs, in particular for the most vulnerable groups [4]. In Burkina Faso, market gardening represented $16.5 \%$ of agricultural production and $4.5 \%$ of the country's gross domestic product in 2002 [5]. Market garden products contribute to the food and nutritional security of populations by supplying vitamins and mineral salts with which they are abundant [4].

In Ouagadougou, the practice of market gardening has experienced a crucial boom since the 1990s [4]. Once only present around dams, it is now practiced around available water points in the city and its surroundings [6]. Ouagadougou has approximately 100 market gardening sites grouped into 28 zones and cultivated over an area of approximately 750 ha occupied by 5000 farmers and 15,000 seasonal workers [7]. Approximately 10 market gardening sites are recognized as the most important, including the 
Boulmiougou and Tanghin sites. However, it appears that these sites are operated in poor sanitary conditions with regard to the unhealthy practices of the operators [4]. The use of wastewater in an uncontrolled manner and without treatment for watering market garden products, associated with the use of pesticides and chemical fertilizers intended for purposes other than market gardening, presents potential risks to human health and the environment [8]. In fact, peasant chemical control practices present real dangers at the following three levels: (i) Toxicity for producers, linked to exposure during the phases of preparation and application of the phytosanitary spray [8]; (ii) toxicity for the consumer, linked to the presence of toxic residues [9]; and (iii) environmental pollution and toxicity to non-target environmental organisms [10].

This study was conducted to evaluate the level of contamination of lettuce and tomato by pesticide residues from the market garden sites of Tanghin, Boulmiougou, Bissigin, and the National School of Public Health (ENSP) of Ouagadougou.

\section{Materials and Methods}

\section{Ethical approval and informed consent}

There was no need of ethical approval for this study. The verbal consent was obtained from each participant before the study.

\section{Study period and sites}

The study was conducted from February to May 2019. This descriptive and analytical study was carried out on urban market gardening sites in the city of Ouagadougou (Figure-1). It was carried out on the market gardening sites of dams n ${ }^{\circ} 1\left(12^{\circ} 23^{\prime} 26^{\prime}{ }^{\circ} \mathrm{N} 1^{\circ} 31^{\prime} 25^{\prime \prime} \mathrm{E}\right)$ and $\mathrm{n}^{\circ} 2\left(12^{\circ} 23^{\prime} 14^{\prime \prime} \mathrm{N} 1^{\circ} 30^{\prime} 56^{\prime}\right.$ ' $\left.\mathrm{E}\right)$ from Tanghin, from Boulmiougou (12 20'15"N $1^{\circ} 35$ '12”'E), from Bissigin $\left(12^{\circ} 23 ' 56^{\prime \prime} \mathrm{N} 1^{\circ} 362^{\prime}\right.$ 'E), from the courtyard of the ENSP $\left(12^{\circ} 23^{\prime} 4^{\prime \prime} \mathrm{N} 1^{\circ} 30^{\prime} 31^{\prime \prime} \mathrm{E}\right)$, and the canal behind the ENSP $\left(12^{\circ} 23\right.$ ' ${ }^{\prime}$ ” $1^{\circ} 30^{\circ} 39^{\prime}$ 'E).

\section{Field investigation}

A descriptive study was conducted on the market garden sites of interest. Sociological approaches such as semi-structured questionnaires, interviews, and direct observation were used to obtain information on cultivation practices from 58 randomly selected market gardeners. The primary information collected concerned socio-demography (age, sex, social status, education level, and primary activity), description of agricultural practices (types of vegetables grown, sources of water supply, irrigation systems, and types of pesticides and fertilizers used), and finally the perceptions of market gardeners on the quality of the vegetables produced.

\section{Collection of lettuce and tomato samples}

A total of 25 lettuces and 25 tomato samples were collected from several market gardeners at random from all sites and transferred into plastic bags (zip bags). All the collected samples were labeled and stored at $+4^{\circ} \mathrm{C}$ in a cooler and then transported to the laboratory for analysis.

\section{Determination of pesticide residues}

Extraction and purification according to the quick, easy, cheap, effective, rugged, and safe (QuEChERS) method

The pesticide residues in the lettuce and tomato samples were quantified according to the QuEChERS method as described by Borowiak et al. [11]. This was performed in three primary stages, namely, extraction, purification, and storage in vials.

\section{Extraction}

The lettuce and tomato samples were cut and then ground using a blender. Next, $5 \mathrm{~g}$ of the ground

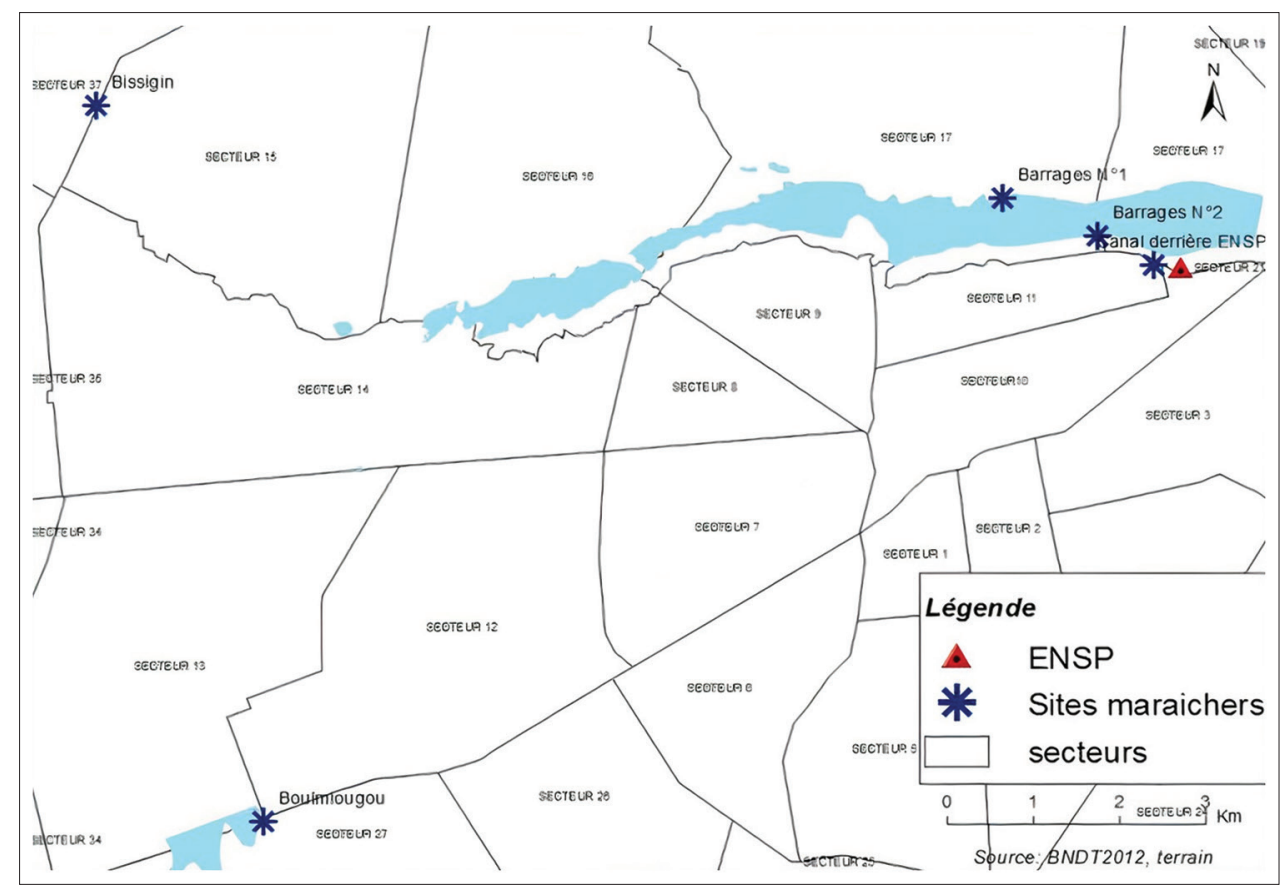

Figure-1: market gardening sites. 
material was weighed and introduced into a $50-\mathrm{mL}$ FALCON centrifuge tube. Then, a set of reagents consisting of $1 \mathrm{~g}$ of sodium chloride, $1 \mathrm{~g}$ of sodium citrate, $0.5 \mathrm{~g}$ of Na-citrate-anhydrous, and $4 \mathrm{~g}$ of magnesium sulfate $\left(\mathrm{MgSO}_{4}\right)$ were added to the contents of the tube. Acetonitrile was used as the extraction solvent. The tube was subjected to vigorous agitation for 1 min using a vortex. Finally, the tube containing the sample and the extraction reagents was centrifuged at $3000 \mathrm{rpm}$ for $5 \mathrm{~min}$.

\section{Purification}

After centrifugation of the sample, a 6-mL aliquot was taken and transferred into a 15-mL FALCON tube containing a purification reagent that was composed of $300 \mathrm{mg}$ of Protein S A, $400 \mathrm{mg}$ of activated carbon (C18), and $900 \mathrm{mg}$ of $\mathrm{MgSO}_{4}$. Acetonitrile was used as the purification solvent. The tube was vortexed for $1 \mathrm{~min}$ and then centrifuged at $3000 \mathrm{rpm}$ for $5 \mathrm{~min}$.

\section{Storage in vials}

In this step, $2 \mathrm{~mL}$ of the supernatant was taken and then transferred into vials, which will be used for analysis by chromatography.

The apparatus used to detect and quantify the pesticide residues is a pair comprising a $\operatorname{Varian}^{\circledR} 431$ GC chromatograph (Agilent Technologies, Les Ulis, France) equipped with an automatic sample changer $\left(\right.$ Varian $^{\circledR}$ CP-8410) and a $\operatorname{Varian}^{\circledR}$ 210-MS (Agilent Technologies) mass spectrometer operating with a charge trapping analyzer. The assembly is linked to a computer equipped with and controlled by the Varianworkstation $^{\circledR}$ software (Agilent Technologies). The chromatograph uses a Zebron ${ }^{\circledR}$ ZB-5MS (Agilent Technologies) brand capillary column (5\% diphenyl, 95\% dimethylpolysiloxane), measuring $30 \mathrm{~m}$ in length, $0.25 \mathrm{~mm}$ inside diameter, and $0.25 \mu \mathrm{m}$ in film thickness, obtained from Phenomenex (Le Pecq, (Messer, Puteaux, France) with a flow rate of $1 \mathrm{~mL} / \mathrm{min}$.

\section{Statistical analysis}

The survey data were processed and analyzed using the Sphinx Millenium 4.5 software, which enabled to generate the descriptive statistics. The mean values of the various study parameters were compared using the Addinsoft XLSTAT 2021.2 software (USA) at a significance threshold of $0.05 \%$.

\section{Results}

\section{Socio-demographic characteristics of market gardeners}

The survey results showed that in the localities covered by the study, there are more women $(55.2 \%)$ than men (44.8\%) who practiced market gardening. The age of the producers ranged from 18 to $>56$ years, with $48.3 \%$ of them being aged between 18 and 35 years. The majority of the surveyed population had a low level of education, with $65.5 \%$ of market gardeners being illiterate and only $10.3 \%$ reaching post-primary education (Table-1). France) and a carrier gas, namely, helium at $99.9 \%$ purity

\section{Speculations produced on market garden sites}

In all the sites, the survey results showed that lettuce (Lactuca sativa L.), amaranth (Amaranthus hybridus), tomato (Solanum lycopersicum), boulvanka (Corchorus tri dens), sorrel (Hibiscus sab dar iffa), kiennebdo (Cleome gynandra L.), and okra (Hibiscus esculentus) were the most frequent speculations during the study period. Cabbage (Brassica oleracea), carrot (Daucus carota subsp. sativus), parsley (Petroselinum crispum), leek (Allium ampeloprasum), bell pepper (Capsicum ann uum), mint (Mentha spicata L.), beet (Beta vulgaris L.), and strawberry (Fragaria ananassa) were also highly produced species.

\section{Knowledge of producers on the health risks associ-} ated with the use of pesticides

The study results showed that less than half of the producers $(41.4 \%)$ recognized the existence of health risks associated with the use of pesticides. Of those producers, $34.5 \%$ linked these health risks to the inhalation of chemicals.

\section{Contamination of lettuce and tomato with pesticide residues}

The results showed that $76.0 \%$ of tomato samples were contaminated with pesticide residues compared with $36 \%$ of lettuce samples.

\section{Pesticide residue concentration}

Based on the chromatographic profile of the lettuce samples collected from the market garden sites, 12 active ingredients were identified, which were divided into the following three families of pesticides: Carbamates, organochlorines, and organophosphates. The chromatographic profile of the tomato samples revealed 17 active ingredients that were also divided into the abovementioned three families of pesticides. Table- 2 shows the distribution of the various compounds according to class. No active ingredient of the synthetic pyrethroid class was found.

\section{Distribution of active ingredients by family}

In lettuce, active organochlorines were the most frequent $(43.8 \%)$, followed by carbamates $(37.5 \%)$ and organophosphates $(18.8 \%)$. Similar observations

Table-1 : Socio-demographic characteristics of the study population.

\begin{tabular}{llcc}
\hline Variables & Categories & Number $\begin{array}{c}\text { Frequency } \\
\text { (\%) }\end{array}$ \\
\hline Gender & Female & 32 & 55.17 \\
& Male & 26 & 44.83 \\
& Total & 58 & 100 \\
Age (years) & $18-35$ & 28 & 48.28 \\
& $36-55$ & 22 & 37.93 \\
& 56 and over & 8 & 13.79 \\
& Total & 58 & 100 \\
Education & Without any education & 38 & 65.52 \\
& Primary & 14 & 24.14 \\
& Post primary & 6 & 10.34 \\
& Secondary & 0 & 0 \\
& Higher Education & 0 & 0 \\
& Total & 58 & 100 \\
\hline
\end{tabular}

International Journal of One Health, EISSN: 2455-8931 
were recorded in tomatoes, with organochlorines (43.4\%) being the most frequent, followed by carbamates $(40.9 \%)$ and organophosphates $(15.7 \%)$.

Concentrations of active ingredients of pesticides present in lettuce and tomato compared to their maximum residue limits (MRL)

Concentration of different active ingredients per

family found in lettuce compared to $M R L$

The results depicted in Figure- 2 show that the concentrations of the quantified active ingredients are statistically higher than the toxicity thresholds, with the exception of diazinon and azoxystrobin whose concentrations were far less than the MRL.

\section{Concentration of different active ingredients per family found in tomato compared to MRL}

As shown in Figure-3, the concentrations of several active ingredients in tomato samples were statistically higher than the MRL.

\section{Discussion}

Market gardening represents a financial opportunity and helps reduce food insecurity. In Ouagadougou, it is often practiced during the dry season around water points. In our study, the population of market

Table-2: Breakdown of active ingredients according to class.

\begin{tabular}{|c|c|c|}
\hline \multirow[t]{2}{*}{ Pesticide classes } & \multicolumn{2}{|c|}{ Active ingredients } \\
\hline & Lettuce & Tomato \\
\hline Organochlorines & $\begin{array}{l}\text { Lindane, HCB, } \\
\text { Chlordimeform, } \\
\text { Chlorothalonil, } \\
\text { Méthazochlore }\end{array}$ & $\begin{array}{l}\text { Lindane, } \\
\text { Heptachlore, } \\
\text { Alpha-endosulfan, } \\
\text { HCB, Chlordimeform, } \\
\text { Chlorothalonil, } \\
\text { Méthazochlore }\end{array}$ \\
\hline Organophosphates & $\begin{array}{l}\text { Diazinon, } \\
\text { Dimethoate }\end{array}$ & $\begin{array}{l}\text { Dimethoate, } \\
\text { Mevinphos, } \\
\text { Monocrotophos, } \\
\text { Heptenophos }\end{array}$ \\
\hline Carbamates & $\begin{array}{l}\text { Quintozene, } \\
\text { Imazalil, } \\
\text { Triadimeform, } \\
\text { Azoxystrobine, } \\
\text { Simazine, } \\
\text { Absence }\end{array}$ & $\begin{array}{l}\text { Quintozene, } \\
\text { Imazalil, Simazine, } \\
\text { Methomyl, } \\
\text { Propiconazol, } \\
\text { Benalaxyl } \\
\text { Absence }\end{array}$ \\
\hline
\end{tabular}

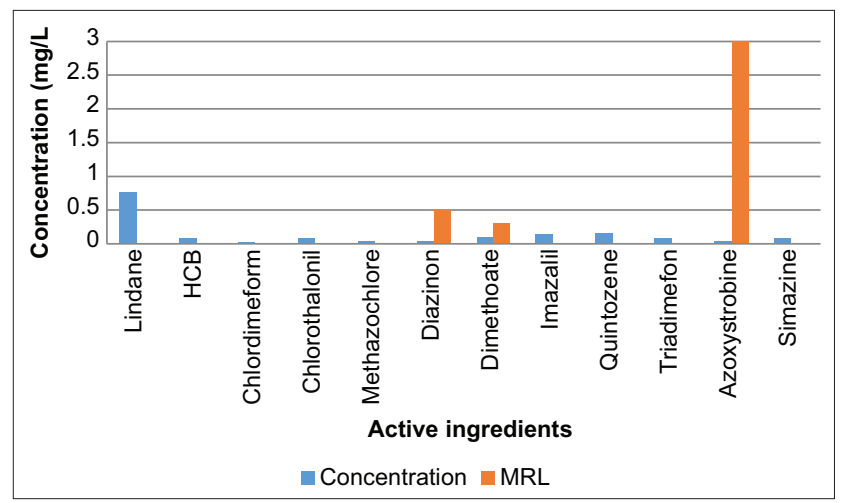

Figure-2: Concentrations of the active ingredients of pesticides present on the lettuce compared to their MRLs. gardeners was predominantly represented by women and a dominant age group between 18 and 35 years. Market gardening allows them to meet their needs and has the resources to finance their primary activities such as education and commerce [12].

The different crops grown correspond to those frequently consumed in Burkina Faso, in fact in the central region. These were exotic (lettuce, tomato, cabbage, carrots, etc.) and traditional vegetables (boulvanka, sorrel, kiennebdo, okra, etc.).

The lack of professional qualification combined with a high unemployment rate limits the possibilities of access to employment for the poorly educated population. Thus, this one comes to the market gardening sector, which does not require a high level of education [13].

The illiteracy of most market gardeners is an obstacle to the appropriate use of pesticides because the instructions for their use are most often written in French and English or sometimes in other languages. This situation could explain the high rate of their ignorance of the dangers related to abusive and uncontrolled use of pesticides. In fact, the lack of information and training on good pesticide use practices has been reported as a major problem by Samake et al. [14]. The low level of education severely limits the knowledge of pesticides, in particular on the application methods, persistence, compliance with withdrawal periods, as well as the precautions to be taken at the time of treatment [15].

According to our study results, 12 and 17 active ingredients were respectively detected in the lettuce and tomato samples with representativeness of the three major families of pesticides organochlorines, organophosphates, and carbamates. Hence, the tomato was the most contaminated speculation among the samples. These results are similar to those obtained by Tarnagda et al. [16], who detected a total of 13 active ingredients in the leafy vegetables examined in their study. These results are also consistent with those obtained by Farag et al. [17] in leafy vegetables sold in the Egyptian market. There was also a predominance of active substances belonging to the organochlorine family, unlike the results of Agnandji et al. [12] and Tarnagda et al. [16],

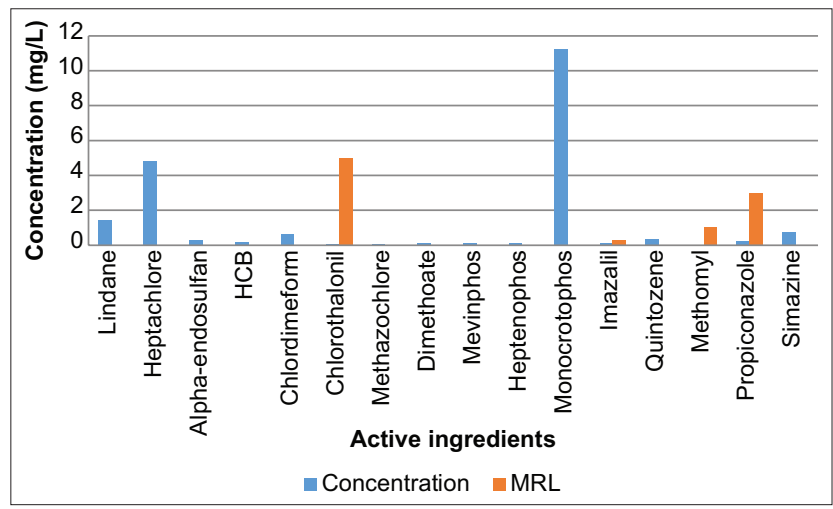

Figure-3: Concentrations of the active ingredients of pesticides present on the tomato compared to their MRLs. 
who, respectively, reported that synthetic pyrethroids and organophosphorus were the most widely used pesticides. Our results reveal a greater persistence of organochlorines in lettuce and carbamates in tomatoes than in other families. This variability in the predominance of active ingredients is attributed to the use of a wide range of pesticides at random, depending on the site and the availability of products.

A comparison of the results obtained using the MRL of Codex Alimentarius, the Sahelian Pesticides Committee, and the European Union revealed the presence of a sample with a toxicity level greater than the standard. In fact, the levels of all the active ingredients were analyzed, with the exception of diazinon and azoxystrobin in lettuce and chlorothalonil, imazalil, methomyl, and propiconazole in tomato, were quantified to be greater than the MRL set. Similar observations were made in other countries in the subregion. For instance, in Kenya, Karanja et al. [18] found excessive levels of diazinon, profenofos, and cypermethrin in leafy vegetables. However, in Benin, similar concentrations of dichlorodiphényltrichloroéthane and lindane were found in samples by Diop et al. [13]. This situation would also infer the use of pesticides not recommended for the treatment of vegetables, such as cotton pesticides, which have a high concentration of active substances and high persistence in the vegetables, or the disregard of the recommended doses and a delay before the harvest [19]. In Ivory Coast, dimethoate and lambdacyhalothrin are the pesticides that are most commonly conveyed by lettuce to consumers [20]. Hence, $90.2 \%$ of these consumers are exposed to the chronic effects of dimethoate, and $97.4 \%$ of them are susceptible to chronic cyhalothrin exposure [20].

Moreover, a concentration of pesticide residues detected in a food sample, even if it is lower than the recommended MRL, should be of major importance. In fact, the presence of pesticide residues in the food chain is a troublesome issue for human health even if their consumption does not immediately present major health risks. Indeed, recent research on the effects of very-lowdose pesticides suggests that current safety levels should be much stricter to properly protect human health, especially that of children and other vulnerable groups as the major health problems related to the daily ingestion of pesticide residues can be neurological and hormonal imbalances and increased cancer risk [21]. Moreover, repeated exposure, reinforced by the accumulative nature of certain substances could present long-term risks and result in pathologies such as immunodeficiency, neurological deficits, reproductive disorders, behavioral abnormalities, and carcinogenesis $[22,23]$. In addition, there are uncertainties about the effects of mixtures of different pesticide residues, which can interact in the body and exacerbate the damage.

\section{Conclusion}

Market gardening contributes to food security and the reduction of the unemployment rate. It generally employs producers with low levels of education. Several categories of exotic and traditional speculations are produced. To optimize yield, growers use pesticides to control pests. This pest control is not without consequences on the quality of the market garden products. Therefore, it is extremely important to educate market gardeners on good practices for the use of pesticides and on alternative methods to synthetic phytosanitary products to protect both their health and that of vegetable consumers against the harmful effects induced by pesticide residues for the sustainability of this activity.

\section{Authors' Contributions}

SSR: Conceptualization, investigation, formal analysis, result analysis, review, and editing of the manuscript. FT and BSRB: Investigation and review of the manuscript. OY: Formal analysis, result analysis, and writing-review. SS: Result analysis and writing-review. EK: Conceptualization, supervision, and review. LS: Conceptualization, supervision, and review. AS: Conceptualization and supervision All authors read and approved the final manuscript.

\section{Acknowledgments}

The study was supported by University Joseph KI-ZERBO and Laboratoire National de Santé Publique (LNSP), Burkina Faso.

\section{Competing Interests}

The authors declare that they have no competing interests.

\section{Publisher's Note}

Veterinary World (Publisher of International Journal of One Health) remains neutral with regard to jurisdictional claims in published map and institutional affiliation.

\section{References}

1. Ouédraogo, R.A., Kambiré, F.C., Kestemont, M. and Bielders, C.L. (2019) Caractériser la diversité des exploitations maraîchères de la région de Bobo-Dioulasso au Burkina Faso pour faciliter leur transition agroécologique. Cah. Agric., 28(20): 9.

2. Abdulkadir, A., Leffelaar, P.A., Agbenin, J.O. and Giller, K.E. (2013) Nutrient flows and balances in urban and peri-urban agroecosystems of Kano, Nigeria. Nutr. Cycl. Agroecosyst., 95(2): 231-254.

3. Son, D., Somda, I., Legrève, A. and Schiffers, B. (2017) Pratiques phytosanitaires des producteurs de tomates du Burkina Faso et risques pour la santé et l'environnement. Cah. Agric., 26(2): 25005.

4. Soma, A. (2020) Cultures maraîchères autour de la zone industrielle de Kossodo à Ouagadougou : Pratiques, circuits de commercialisation et risques sur la santé des citadins. Rev. Espac. Territ. Soc. Santé, 3(5): 55-61.

5. Ministère de l'Agriculuture, de l'Hydrolique et des Ressources Halieutiques. (2007) Analyse de la Filière Maraichage au Burkina Faso. EASYPol, Ministère de l'Agriculuture, Paris, France.

6. Ouedraogo, R.U.E., Nikiema, D.E.Y. and Yanogo, P.I. (2018) le dechet a toyiibi : Interface entre le citadin et son espace de vie. Rev. Espac. Territ. Soc. Santé, 1(1): 133-146. 
7. Conchita, M.G., Kêdowidé, M., Sedogo, P. and Guéladio, C. (2010) Dynamique spatio temporelle de l'agriculture urbaine à Ouagadougou : Cas du Marâichage comme une activité montante de stratégie de survie. VertigO la Rev. Electroniq. Sci. Environ., 10(2): 23.

8. Ngom, S., Traore, S., Thiam, M.B. and Manga, A. (2012) Contamination des produits agricoles et de la nappe phréatique par les pesticides dans la zone des Niayes au Sénégal. Rev. Sci. Technol., 25(2012): 119-130.

9. Maroni, M., Fanetti, A.C. and Metruccio, F. (2006) Risk assessment and management of occupational exposure to pesticides in agriculture. Med. Lav., 97(2): 430-437.

10. Adjovi, I.S.M., Adjovi, C.Y.S., Ayi-Fanou, L. and Ayandji, P.S.A. (2020) les pratiques d utilisation des pesticides par les maraichers au les pratiques d'utilisat ion des pesticides par les maraichers au benin: Perspectives sociologiques. Glob. J. Arts Hum. Soc. Sci., 8(2): 22-45.

11. Borowiak, K., Zbierska, J., Baralkiewicz, D., Hanc, A., Budka, A., Kayzer, D. and Kawala, A. (2014) Biomonitoring of air pollution by trace elements using Italian ryegrass (Lolium multiflorum L. Lema). Polish J. Environ. Stud., 23(3): 681-688.

12. Agnandji, P, Cachon, B.F., Atindehou, M., Adjovi, I.S.M., Sanni, A. and Ayi-Fanou, L. (2018) Analyse des pratiques phytosanitaires en maraîchage dans les zones intra-urbaines (Cotonou) et péri-urbaines (Sèmè-kpodji)'. Rev. Afr. Environ.Agric., 1(1): 2-11.

13. Diop, A., Diop, Y.M., Thiare, D.D., Cazier, F., Sarr, S.O., Kasprowiak, A., Landy, D. and Delattre, F. (2016) Monitoring survey of the use patterns and pesticide residues on vegetables in the Niayes zone, Senegal. Chemosphere, 144(2016): 1715-1721.

14. Samake, F., Babana, A.H., Yaro, F.K., Cisse, D., Traore, I., Kante, F., Kone, S., Diallo, A., Toure, H., Toure, O., Sako, M. and Ag Iknane, A. (2011) Risques sanitaires liés à la consommation des produits maraîchers cultivés dans la zone urbaine et périurbaine de Bamako. Medical risks related to the consumption of the market-gardening products cultivated in the urban and periurbaine zone of Bamako. Mali. Santé Publique, 1(1): 27-31.

15. Kanda, M., Djaneye-Boundjou, G., Wala, K., Gnandi, K., Batawila, K., Sanni, A. and Akpagana, K. (2013) Application des pesticides en agriculture maraichère au Togo. VertigO., 13(1): 13456.
16. Tarnagda, B., Tankoano, A., Tapsoba, F., Sourabié, P.B., Abdoullahi Hissein, O., Djbrine Adoum, O., Drabo, K.M., Traoré, Y. and Savadogo, A. (2017) Évaluation des pratiques agricoles des légumes feuilles: Le cas des utilisations des pesticides et des intrants chimiques sur les sites maraîchers de Ouagadougou. J. Appl. Biosci., 117(2017): 11658-11668.

17. Farag, R.S., Abdel Latif, M.S., Abd El-Gawad, A.E. and Dogheim, S.M. (2011) Monitoring of pesticide residues in some Egyptian herbs, fruits, and vegetables. Int. Food Res. $J ., 18(2):$ 659-665.

18. Karanja, N.K., Njenga, M., Mutua, G.K., Lagerkvist, C.J., Kutto, E. and Okello, J.J. (2012) Concentrations of heavy metals and pesticide residues in leafy vegetables and implications for peri-urban farming in Nairobi, Kenya. J. Agric. Food Sys. Community Dev., 3(1): 255-267.

19. Son, D., Somda, I., Legreve, A. and Schiffers, B. (2018) Effect of plant diversification on pest abundance and tomato yields in two cropping systems in Burkina Faso: Farmer practices and integrated pest management. Int. J. Biol. Chem. Sci., 12(1), 101.

20. Yao, B.L., Kpan, G.K.K., Messoum, F.G., Dembele, A. and Traore, K.S. (2016) Évaluation du risque phytosanitaire lié à la consommation de la laitue (Lactuca sativa) cultivée dans la commune de Port-Bouët (Abidjan). Rev. Mar. Sci. Agron. Vét., 4(3): 23-30.

21. PAN. (2012) A Generation in Jeopardy: How pesticides are undermining our children's Health and Intelligence (Une génération en péril: Les pesticides endommagent la santé physique et mentale de nos enfants), PAN Amérique du Nord et Californians for Pesticide Reform; 2012. Available from: http://www.panna.org/publication/generation-in-jeopardy Retrieved on 21-09-2021.

22. Traore, K., Dembele, A., Mamadou, K., Mambo, V., Lafrance, P., Bekro, Y.A. and Houenou, P. (2008) Contrôle des pesticides organochlorés dans le lait et produits laitiers: Bioaccumulation et risques d'exposition. Afr. Sci., 4(1): 87-98.

23. Kouadio, D., Ehouman, S., Soro, B., Diarra, M., Doumbia, M., Meite, L., Mamadou, K., Dembele, A. and Traore, S. (2014), Contamination du lait caillé et de l'œuf consommé en Côte d'Ivoire par des pesticides organochlorés. Afr. Sci., 10(4): 61-69. 